\title{
On Fennoscandian polypores 8. New genus Piloporia
}

\author{
TUOMO NIEMELÄ
}

\begin{abstract}
NIEMELÄ, T. 1982: On Fennoscandian polypores 8. New genus Piloporia. - Karstenia $22: 13-16$.

The species of the newly described monotypic polypore genus Piloporia Niemelä resembles those of the genus Datronia Donk in the brown hyphae and the distinctly duplex structure of the fruit body context, but differs in having allantoid sopres and encrusted hyphal tips in the pore mouths. The two last-mentioned characters show affinity to Incrustoporia Domański, but the brown colouration and duplex context separate Piloporia from that genus.

The only species, $P$. sajanensis (Parm.) Niemelä n.comb. (Antrodia sajanensis Parmasto), is reported as new to Finland, having been collected on Pinus sylvestris. The macroscopical and microscopical features are described and illustrated, and the taxonomy discussed. The world distribution of the species is surveyed, the present locality being the sixth that is known. All the collections have been made in slightly to distinctly continental parts of the Northern boreal zone in Eurasia.

Tuomo Niemelä. Department of Botany, University of Helsinki, Unioninkatu 44, SF00170 Helsinki 17, Finland
\end{abstract}

\section{Piloporia Niemelä n.gen.}

Genus polyporaceosum, simile generis Datronia. Ab eo differt sporis allantoideis et incrustohyphis in marginibus tubulorum sitis. A generibus Incrustoporiae et Skeletocutis differt colore brunneo et structura duplici contextus. - Typus: Antrodia sajanensis Parmasto.

Hyphal system dimitic, generative hyphae with clamp connections. Both generative and skeletal hyphae brown in context and subiculum; context and subiculum duplex with a distinct, thin, brownish black separating layer. Spores allantoid or lunate; pore mouths with incrustohyphae. Differs from Datronia Donk in having narrow spores and incrustohyphae, from Incrustoporia Domański and Skeletocutis Kotl. \& Pouzar in the brown pigmentation of the hyphae and the duplex structure of the context and subiculum.

\section{Piloporia sajanensis (Parm.) Niemelä n.comb.}

Antrodia sajanensis Parmasto, Bot. Mater. Otdela Spor. Rast. Bot. Inst. Akad. Nauk SSSR 15: 134. 1962. Holotypus: U.S.S.R., Krasnojarskij kraj. Manskij rajon, Badžej, Abies sibirica, 1958 Parmasto 9738 (TAA). - Datronia sajanensis (Parm.) Domański, Mała flora grzybów 1(1): 196. 1974. - Incrustoporia sajanensis (Parm.) Strid, Wahlenbergia 7: 138. 1981.
Finland. Enontekiön Lappi: Enontekiö, Ketomella, north of Takavuoma, log of Pinus sylvestris in a clear-cut area, alt. $330 \mathrm{~m}, 31$.VIII.1980 Tuomo Niemelä 2175 \& Heikki Kotiranta (herb. $\mathrm{H}$ and T.N.).

Fruit body annual, resupinate or effused-reflexed. Consistency soft corky throughout, not hardening when drying. Upper surface of the pileoli cigar brown, pore surface at first white with a tint of sepia, finally light greyish sepia, darkening only slightly when bruised. Pilei variable, in Finnish material almost lacking, in others up to $8 \mathrm{~cm}$ wide, projecting up to $2.5 \mathrm{~cm}$, ca. $0.5 \mathrm{~cm}$ thick. Subiculum and pilear context in section duplex: upper layer $0.1-0.5(-1)$ mm thick, cigar brown, spongy; dividing line coffee brown to black, distinct, $0.02-0.04 \mathrm{~mm}$ thick; lower layer light cork-coloured, $0.1-0.3 \mathrm{~mm}$ thick. Tubes in section concolorous with the lower layer of the context. Pores (3-) 4-5 per $\mathrm{mm}$, initially roundish to angular, later sometimes fusing together to form sinuous or (in oblique parts) even lamellate splits, pore mouths pruinose, under lens $(\times 50)$ ciliate, finely dentate and in parts lacerate.

Hyphal system dimitic. Upper context with brown hyphae, which are (2.5-) 3-4 $\mu \mathrm{m}$ in diam, thickwalled to subsolid, flexuose, loosely interwoven, with few but regularly occurring clamps and very few branches, xanthochroic: intermixed with scattered hyaline hyphae, which are thin-walled, branched and nodose-septate. Dividing line consisting mostly of brown hyphae (as above), tightly packed and embedded in resinous matter. Lower context dimitic with abundant generative hyphae $2-3(-4) \mu \mathrm{m}$ in diam, 


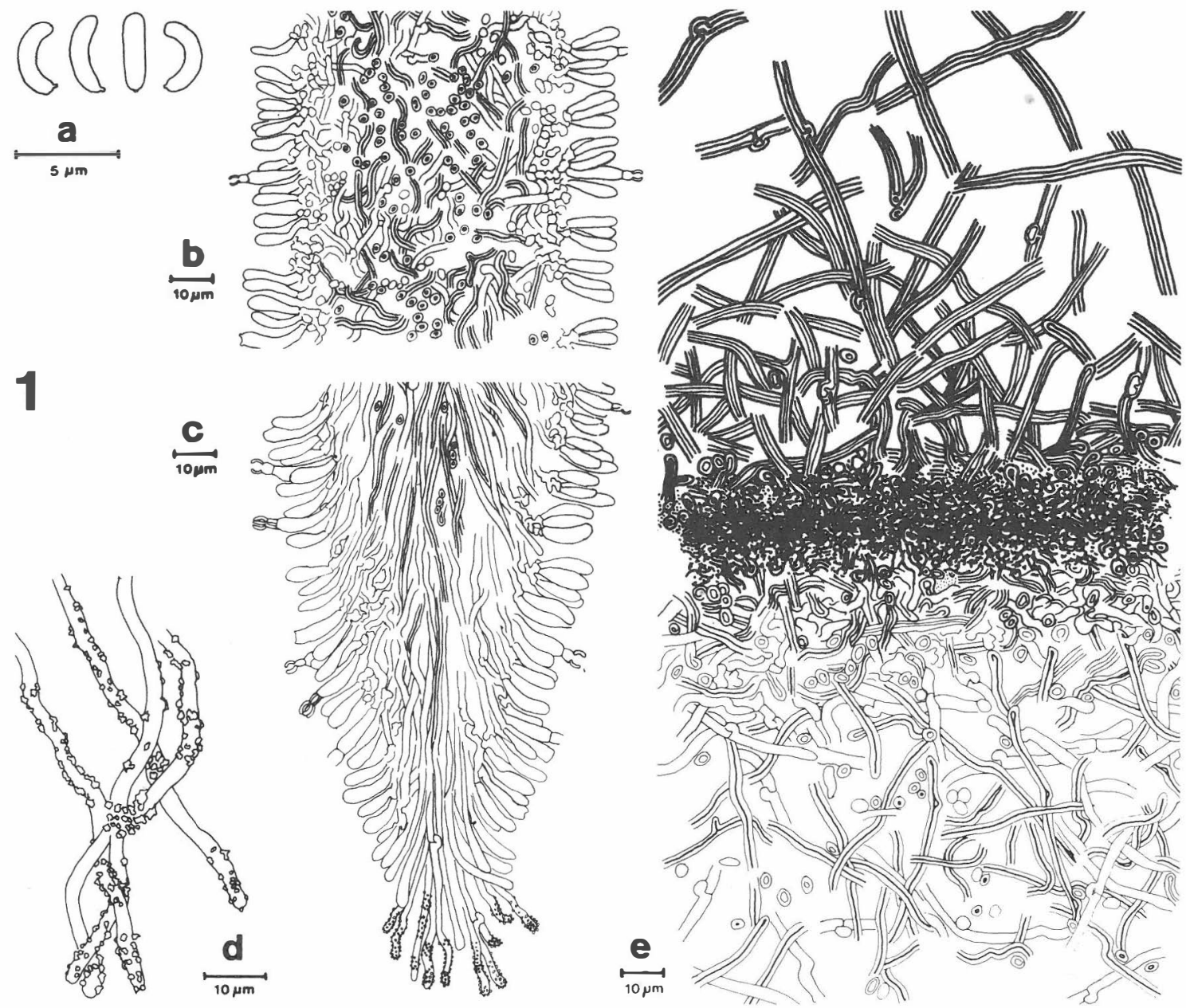

Fig. 1. Piloporia sajanensis. a) spores, b) dissepiment in vertical section, c) dissepiment edge, d) encrusted hyphal tips from dissepiment edge, e) section through context, showing duplex structure with a pigmented upper part and non-pigmented lower part separated by a dark layer (specimen Niemelä 2175 \& Kotiranta, T.N., H).

hyaline, branched and nodose-septate; skeletal hyphae numerous, $2-3 \mu \mathrm{m}$ in diam, fuscous yellow, subsolid, the two types densely interwoven. Hymenial trama with hyaline generative hyphae $(1-)$ 1.5-2.5 $\mu \mathrm{m}$ in diam, and almost hyaline, subsolid skeletal hyphae $1-2 \mu \mathrm{m}$ in diam, the two types interwoven. Subhymenium ca. $5 \mu \mathrm{m}$ deep, not well delimited. No hymenial cystidia or cystidioles (Strid 1981 reports cystidioles, which seem to be elongated basidioles in old deteriorating hymenium. None could be seen in the fertile hymenium of the Finnish specimen.). Dissepiment edges with undulating hyphae, densely encrusted for a length of $10-25 \mu \mathrm{m}$. Hymenium with dense palisade of basidia $12-13 \times 3.5-4 \mu \mathrm{m}$ and basidioles $11-12 \times 3.8-4 \mu \mathrm{m}$, soon collapsing. Sterigmata four per basidium, $2 \mu \mathrm{m}$ long. Spores $3.8-$ $3.9(-4.1) \times 0.8-0.9 \mu \mathrm{m}$, allantoid, almost lunate, nonamyloid, indextrinoid, acyanophilous.
Causes white rot on dead coniferous wood.

\section{Taxonomy}

Some comments are needed on the generic position of $P$. sajanensis. When describing the species, Parmasto (1962) placed it in the genus Antrodia Karst. At that time the typification of the genus had not been worked out, and the common concept was changed completely by Donk (1960), who typified Antrodia with Trametes serpens (Fr.) Fr., and erected the new genus Datronia Donk for Trametes mollis (Sommerf.) Fr. and allied species (Donk 1966). Therefore, by transferring the present species into Datronia, Domański (1974) in fact restored the original meaning of Parmasto. The new combination was not indicated as such by Domański (1974), but otherwise it was made 
according to the Code (cf. Anonym. 1975: 306).

$P$. sajanensis was included in the same genus with Datronia mollis (Sommerf.) Donk and D. epilobii (Karst.) Donk ( $=D$. stereoides auct.) mainly because of the features of the context. It is very distinctly duplex, two soft layers being separated by a thin, hard, almost black stratum: a feature characteristric of the genus Datronia. Further, all the species are dimitic with brown xanthochroic hyphae, which give colour to the whole fruit body. Donk (1974) listed the species under Datronia, but did not make the new combination.

P. sajanensis has some features, however, which are not characteristic of Datronia. Above all, its spores are notably smaller and thinner in shape, and the pore mouth hyphae are encrusted. This led Strid (1981) to transfer the species to the genus Incrustoporia Domański. The reasons for this transfer are clear, but $P$. sajanensis has characters which would obscure the clear-cut concept of the genus Incrustoporia: the brown pigmentation of the hyphae, the distinctly duplex structure of the context and the soft spongy consistency of the context even in the dry state. Besides, the encrustation of the pore mouth hyphae is not a character exclusive to Incrustoporia. Similar hyphae are found in the species of Skeletocutis Kotl. \& Pouz. (Tortić \& David 1981), and somewhat coarser hyphal tip encrustation exists in Fibuloporia Bond. \& Sing. (Domański 1969). In spore form and hyphal structure Poria lenis (Karst.) Sacc. resembles $P$. sajanensis, but it and the species of Skeletocutis and Fibuloporia all differ in having colourless hyphae and a homogeneous context.

In summary, Piloporia is a genus intermediate between Datronia and Incrustoporia, but differing clearly from them both. Jülich (1981) placed Datronia in the family Coriolaceae and Incrustoporia in Incrustoporiaceae, both of which belong to the order Coriolales. The existence of Piloporia casts doubts on the division of the genera between two families.

Although the generic placement of $P$. sajanensis has been the subject of some controversy, the concept of the species itself is clear. I do not know any other species which could be confused with this one, characterized by a duplex context, a dimitic hyphal system with brown contextual hyphae, allantoid spores and encrusted hyphal tips.

\section{Distribution and ecology}

According to present knowledge, Piloporia sajanensis is a very rare species. Three localities are known in Siberia: the easternmost lies in the Soviet Far East, Yakut A.S.S.R., Khonu, by the River Moma. The species was described from the Krasnojarsk Territory, Mansk District, northern slope of the Sayan Mts.

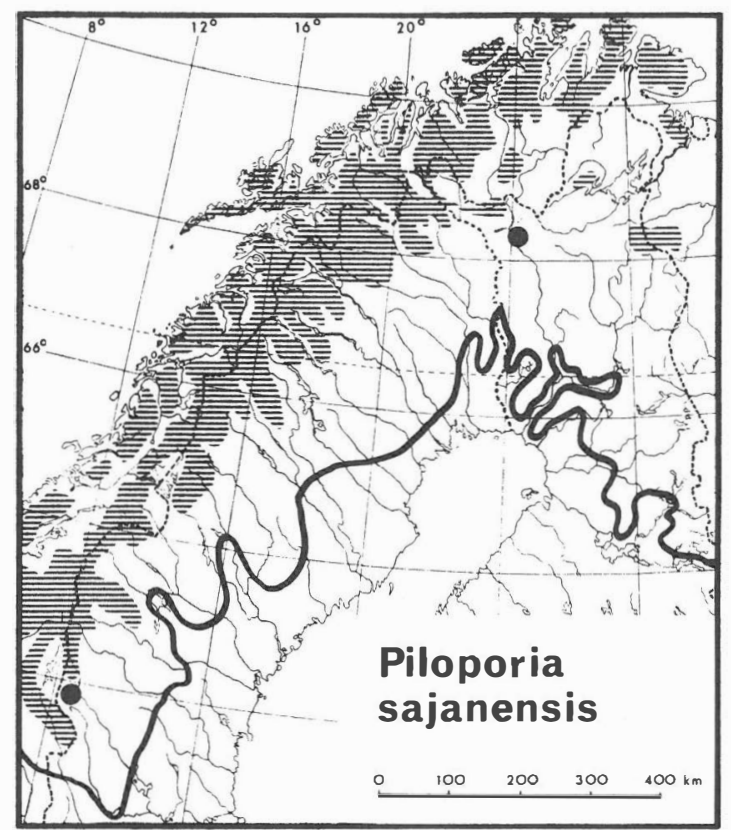

Fig. 2. The occurrence of Piloporia sajanensis in Fennoscandia (dots). The shaded areas are the Orohemiarctic and Oroarctic montane parts, not included in the Northern boreal zone. The black line shows the southern limit of the Northern boreal zone.

The third Asian find is from the Tjumen' Region, Krasnosel'kup, by the River Taz. Two earlier localities have been reported from Europe: Komi A.S.S.R., Kočmes, NW slope of the Urals, and Sweden, Dalarna, Idre (Parmasto 1962, 1967, Strid 1981).

The present find is by far the most northern, lying over $200 \mathrm{~km} \mathrm{~N}$ of the Arctic Circle. The finds from Moma, Taz and Kočmes are situated less than 100 kilometres south of the Arctic Circle. The Swedish find is ca. $200 \mathrm{~km}$ south of it, but was made on a fjeld slope at $600-700 \mathrm{~m}$. The type locality is the southernmost $\left(\mathrm{ca} .55^{\circ} \mathrm{N}\right)$, but the altitudes of those mountain slopes vary between 1000 and $1500 \mathrm{~m}$.

According to these data, the distribution of $P$. sajanensis falls within the Northern boreal subzone of the circumboreal zone (Hämet-Ahti 1981), not far from the northern (in the mountains upper) coniferous tree line. Climatically, these sites belong in the slightly continental (Fennoscandia) or distinctly continental (the U.S.S.R.) sectors of the subzone (Ahti et al. 1968). In fact, Strid (1981) indirectly predicted the find of the species in North Finland, when he noted its preference for a continental climate (calling it a 'taiga species'), and mentioned the two areas in Fennoscandia where the conditions best approximate to such a climate: the eastern 'shadow' of the Scandes (where Strid made his find) and the inner parts of northern Sweden and Finland. 
$P$. sajanensis is a wood-rotting fungus of conifers. Earlier, it has been reported on Abies sibirica, Larix gmelinii (L. dahurica), L. sibirica, and Picea abies ssp. abies and ssp. obovata (Parmasto 1962, 1967, Domański 1974, Strid 1981). The Finnish collection from Pinus sylvestris thus adds a new host to the list. The present find was made on a rotten log, left behind in a clear-cut area on a low fjeld top. The forests are very sparse there, consisting chiefly of Betula pubescens ssp. tortuosa. which is intermixed with Pinus and some of the northernmost populations of Picea abies. The same log also harboured Trichaptum laricinum (Karst.) Ryv. and still unnamed conifer-dwelling species of the Antrodiella semisupina complex.

Acknowledgements. I wish to thank Dr. Åke Strid (Stockholm) for sending me reference material. The English of this paper was revised by Mrs Anna A. Damström, M.A.

The work was supported by a long-term grant from the Academy of Finland.

\section{References}

Ahti, T., Hämet-Ahti, L. \& Jalas, J. 1968: Vegetation zones and their sections in northwestern Europe. - Ann. Bot. Fennici 5: 169-211.
Anonymus 1975: Index of Fungi 4(10): 301-335.

Domański, S. 1969: Grzyby zasiedlające drewno w Puszczy Bialowieskiej 10. Fibuloporia subvermispora (Pilát) Domański, comb. nov. i jej rozpoznanie. - Acta Soc. Bot. Poloniae 38: 453-464.

- 1974: Mała flora grzybów (1). Basidiomycetes, Aphyllophorales: Bondarzewiaceae, Fistulinaceae, Ganodermataceae, Polyporaceae. - 316 pp. Warszawa \& Kraków.

Donk, M. 1960: The generic names proposed for Polyporaceae. - Persoonia 1: 173-302.

- 1966: Notes on European polypores 1. - Persoonia 4: 337-343.

- 1974: Check list of European polypores. - 469 pp. Amsterdam.

Hämet-Ahti, L. 1981: The boreal zone and its biotic subdivision. - Fennia 159: 69-75.

Jïlich, W. 1981: Higher taxa of Basidiomycetes. - 485 pp Vaduz.

Parmasto, E. 1962: Novye vidy i raznovidnosti gribov. Tremellales i Aphyllophorales. - Bot. Mater. Otdela Spor. Rast. Bot. Inst. Akad. Nauk SSSR 15: 125-137.

- 1967: Trutovye griby severa Sovetskogo Sojuza. - Mikol. Fitopatol. I: $280-286$.

Strid, A. 1981: Incrustoporia sajanensis (Parm.) comb.nov. (Polyporaceae), a taiga species new to Fennoscandia. -Wahlenbergia 7: 135-139.

Tortic, M. \& David, A. 1981: Skeletocutis jelicii nov.sp. (Polyporaceae). - Bull. Mensuel Soc. Linnéenne Lyon 50: $217-219$.

Accepted for publication

on May 13, 1982 